\title{
Assessing the Impact of Knowledge of Government Business Support Services on Propensity of New Graduates to Venture into Business
}

\author{
Mohd Nor Hakimin Yusoff ${ }^{1}$, WM. Nazdrol Bin WM. Nasir ${ }^{1} \&$ Fakhrul Anwar Bin Zainol ${ }^{2}$ \\ ${ }^{1}$ Faculty of Entrepreneurship and Business, University Malaysia Kelantan, Kelantan, Malaysia \\ ${ }^{2}$ Faculty of Business Management and Accountancy, Universiti Sultan Zainal Abidin, Terengganu, Malaysia \\ Correspondence: Mohd Nor Hakimin Yusoff, Faculty of Entrepreneurship and Business, University Malaysia \\ Kelantan, Malaysia. E-mail: hakimin@umk.edu.my
}

Received: April 29, 2012 Accepted: July 16, 2012 Online Published: August 16, 2012
$\begin{aligned} & \text { doi:10.5539/ijbm.v7n16p106 } \\ & \text { URL: http://dx.doi.org/10.5539/ijbm.v7n16p106 }\end{aligned}$

\begin{abstract}
As part of its SME development agenda in the country, the Malaysian government promotes entrepreneurship as a career among university students by offering educational programs at local universities in form of core subjects or part of the curriculum. Nevertheless, the impact of this strategy has not been satisfactory as these programs have not been able to encourage young graduates to venture into entrepreneurial activities. Young entrepreneurs often lack the capital for starting a business or face technical problems in executing and developing a business idea. To help young entrepreneurs overcome these obstacles, government business support services (GBSS) has been set up to provide them every possible help to start their own business. This paper examines if knowledge of GBSS is a positive factor that can assure young graduates of receiving the requisite support and encourage them to set up their own business. Using a quantitative technique, this study measures the impact of awareness of GBSS, product knowledge and procedural knowledge of acquiring the services among potential graduates on their intention to pursue a business opportunity. Data analyses were conducted via two principal stages using SPSS 19.0 and Smart PLS 2.0. This study found that while awareness of the GBSS and knowledge about the procedure of acquiring a service affect the readiness of potential entrepreneurs to venture into their own business, interestingly, product knowledge about the service offered did not have a significant impact at all.
\end{abstract}

Keywords: government business support, entrepreneurship, young graduates, partial least square

\section{Introduction}

As part of its overall goal to boost entrepreneurship and commerce in the country, the Malaysian government has launched many initiatives to promote entrepreneurship as a viable and lucrative career among university students. But the impact of these initiatives has not been satisfactory since a very low percentage of graduates have actually managed to venture successfully into entrepreneurial activities after leaving college. A census conducted by the Ministry of Higher Learning indicated that only $2.4 \%$ of local graduates venture into business compared to $10 \%$ in USA. Till date no empirical study has been conducted to examine the reasons for this unsatisfactory result. The government provides a range of support services to aid the development of SMEs in Malaysia. But in spite of these support services, the rate of conversion of graduates into successful entrepreneurs has continued to stagnate at very low levels.

This paper attempts to examine the role of the government business support services (GBSS from here on) in influencing the intention of students in taking up entrepreneurship as a career. Most studies on graduate entrepreneurship adopt a psychological perspective to discuss the link between personality traits, attitudes, tacit knowledge and entrepreneurial intention (Luthje \& Franke, 2003). On the other hand, acknowledged by Resource Base View (RBV) theory acknowledges the role played by external support in influencing the intention of prospective entrepreneurs in starting up a business.

This study synthesises a psychological perspective with RBV theory to measure the influence of support services on the intention of new graduates to start their own business. It employs the variables of awareness, product knowledge and procedural knowledge and uses a quantitative technique to measure the overall awareness of GBSS among a sample of students from two public universities in Malaysia and its impact on their intention to pursue entrepreneurial activities. It must be noted here that knowledge of procedure in acquiring GBSS 
assistance has not been tested before as a part of research model in any study. Another strength of this study is that it is based on actual fieldwork conducted among young graduates in Malaysia. A ten year literature review by Gorman, Hanlon and King (1997) found that 15 studies have been conducted on the topic of entrepreneurial intention, but out of this, only 8 studies were conducted as empirical research on actual graduates.

The paper is structured in the following manner. Section 2 presents a literature review discussing the issue of student entrepreneurship, previous studies measuring the intention of students to pursue entrepreneurship and argues for exploring the impact of GBSS on this issue. Then, section 3 presents the research problem of the study viz. the slow uptake of entrepreneurial careers among young graduates and the role of GBSS in Malaysia. Section 4 will propose a research framework for the study. It elaborates three different variables derived from previous studies - awareness, procedural knowledge and product knowledge - and proposes hypotheses for each construct for measuring the impact of overall awareness about GBSS on student intention to pursue entrepreneurial activities. Section 5 presents the analysis conducted on a sample of students from two public universities in Malaysia, including a test of the goodness of the measures used in the research framework and findings of the study regarding the hypotheses proposed for each construct. Finally, section 6 concludes the paper with a discussion of the findings and some implications for practitioners derived from the analysis. Thus, this study provides insight into the impact of GBSS on the propensity of new graduates to venture into business in Malaysia and makes some suggestions for policy makers and academic scholars to improve awareness of GBSS.

\section{Research Context}

\subsection{Entrepreneurship among New Graduates}

Entrepreneurship plays an important role in supporting economic activities in the country by creating job opportunities and boosting commerce, thus contributing to the country's gross domestic product (National SME Development Council, 2009). Besides the creation of wealth, entrepreneurial activities are also seen as reducing people's dependence on the government for providing job opportunities. Previous studies have shown that entrepreneurship is a skill that can be learned. These studies argue that a person is neither born nor fated to be an entrepreneur. The skills behind becoming a successful entrepreneur are not the result of a person's inherent personality or genetic makeup but can be honed through training and nurturing. Thus it has been argued that Most of what you hear about entrepreneurship is all wrong. It's not magic, it's not mysterious; and it has nothing to do with genes. It's a discipline and, like any other discipline, it can be learned (Drucker (1994) in Tan and Ng (2006)).

On the basis of this claim, researchers across the world have approved the implementation of entrepreneurship as a subject to be taught in professional education. Accordingly, entrepreneurship programs are offered by local universities in Malaysia either as a core subject or embedded in the curriculum to teach requisite skills to graduate entrepreneurs and encourage students to choose entrepreneurship as a career.

\subsection{Previous Literature on Student Entrepreneurship}

There is extensive research in the literature discussing various issues around graduates in entrepreneurship activities. In general, identifying the factors influencing student intention to adopt entrepreneurship as a career has emerged as the main area of interest in research on students and entrepreneurship. However, these studies largely explore the role of social and psychological factors behind student intention to venture into business. Many studies on graduate entrepreneurship use a psychological perspective to discuss the link between personality traits, attitudes, tacit knowledge and perceptions about barriers to business on intention to pursue a career in entrepreneurship (Luthje \& Franke, 2003). Some other studies examine the role of social background and enumerate a number of social factors that can influence students to venture into business, namely, students attitudes, training programs, culture and family background, awareness (Gorman, et al., 1997) and awareness about entrepreneurial activities (Dahlan, Hakimin, \& Azwin, 2010). Delmar and Davidsson (2000) list some additional factors such as gender, work experience, educational background, age and professional background. A recent study by Soutaris, Zerbinati and Al-Laham (2007), using the 'theory of planned behaviour', found that educational programs also have an influence on students' attitudes and intentions towards an entrepreneurial career.

These studies rarely include the role of external support and their impact on attitudes and perceptions of prospective student entrepreneurs. Apart from psychological or social factors, practical matters of financial or logistical resources are of critical importance in setting up a business. And here, the actual support services available to a potential entrepreneur can not only give him the material help needed for the business but boost his morale in pursuing his idea. Regardless of strong personal motivation or positive social environment, if a 
prospective entrepreneur does not receive the requisite support his efforts at establishing a business will be frustrated.

\subsection{Focussing on the Role of GBSS on SMEs}

The role played by external support in influencing the intention of prospective of entrepreneurs has been acknowledged by Resource Base View (RBV) theory. The central focus of RBV is identifying the unique resources possessed by firms which can be categorized as valuable, rare, inimitable and different. Firms that are able to acquire unique resources have a greater chance of sustaining competitive advantages in the market (Barney, Wright, \& Ketchen, 2001; Penrose, 2009). However, in small and medium enterprises, a myriad of weaknesses such as small capital, limited network or deficient human resources can become a major obstacle for gaining competitive advantages. To some extent, the disadvantages of being a small enterprise are quite substantial and can pose a threat to a firm's survival. From personal experience and long-term observation as an executive in a prominent development institution in the country, the author believes that the major reasons behind the failure of new graduates in becoming entrepreneurs are inability to raise capital to start the business and technical problem in executing and developing the business idea.

To overcome such obstacles, SMEs need external assistance in managing their operations. External support can come from two main sources - public sector (government) and private supplier. GBSS forms a strong component of external support for prospective entrepreneurs in small and middle enterprises. The need for assistance services from relevant government agencies are essential for micro-sized SMEs as they cannot afford to pay for private service providers. As a general rule, SMEs face difficulties in accessing resources from private support providers due to many limitations (Moha Asri, Abdul Aziz, Mohd Isa, \& Norizan, 2001; Mole, Hart, Roper, \& Saal, 2009; Salleh \& Ndubisi, 2006; Wren \& Storey, 2002). For instance, most of them face problems in obtaining loans from financial institutions due to stringent terms and conditions of a loan contract and lack of documentation about the firm which is needed for any bank loan. In many situations government-sponsored programmes offer a more flexible and generous funding solution than private providers; government-sponsored financial programs may also agree to give loans to a new business and take risks by participating in starting up a business which is considered a risky stage in the business cycle.

\section{Research Problem}

GBSS has been widely discussed in the literature and researchers have been using theories related to resources based view and networking to study the impact of GBSS on the performance of the beneficiary firms (Bennett \& Robson, 1999; Berry, Sweeting, \& Goto, 2006; Chrisman, Mc Mullan, \& Hall, 2005; Ramsden \& Bennet, 2005). However, there is a lot of debate about the actual impact of GBSS on SMEs. While some studies have found a positive relationship between the use of business assistance from GBSS by SMEs with the growth of their businesses (1999; Berry, et al., 2006; Caniels \& Romjin, 2006; Dyer \& Ross, 2008) or positive impact in certain areas (Caniels \& Romjin, 2006; Dyer \& Ross, 2008), other authors have found that external support from the government has not impact whatsoever on SMEs performance. It has been noted that GBSS sponsored programs are not fully utilized by SMEs (Berry, et al., 2006; Boter \& Lundstrom, 2006; Ramsden \& Bennet, 2005). (Wiklund \& Shepherd, 2003) found that regular contact with GBSS agencies result in a favourable influence on the growth of the small businesses and Berry et al., (2006) found that owners who frequently sought business assistance services experienced positive growth compared to those who did not. Bennet and Robson (1999) proposed that the impact is only marginal for SMEs in the services sector but significant for SMEs in the manufacturing sector. These mixed results reported in the literature has motivated Chrisman, Mc Mullan and Hall (2005) to question the rationale behind spending huge amounts of taxpayer money on providing government support services to SMEs when the result of such effort is questionable or uncertain.

In spite of this criticism and debate about the actual impact of GBSS on SMEs, GBSS forms the mainstay of external support for SMEs in Malaysia providing support to SMEs in all phases of the business cycle ranging from start-up to expansion and rehabilitation. For example, the government has provided some programs to assist young graduates to venture into business after college. One program called Young Graduates Fund provides monetary support for the initial capital to young graduates who aim to start a business. Besides that, a number of related schemes such as marketing support, technical support and human resources support are also available to all SMEs.

However, in spite of the efforts made by the government, the situation of SMEs in Malaysia indicates that the business assistance services provided by the government are grossly underutilized. For example, a local study conducted by Abdul Aziz and Faoziah Foziah, Aziz and Sudin (2009) found that SMEs in Malaysia prefer to deal with commercial banks over government agencies to obtain financial support. It has been noted that apart from a 
few programs that have been able to penetrate the market, the government support programs are generally unpopular among SMEs (Berry, et al., 2006; Jay \& Schaper, 2003) Foziah et al., 2006). Here, the high level of bureaucracy and stringent terms and conditions has often been identified as a factor discouraging SMEs from dealing with GBSS (Abdul Aziz \& Faoziah, 2009; Hakimin, 2010; Khairudin, 2007; Salleh \& Ndubisi, 2006).

While it is recommended that the quality of service and delivery of GBSS be improved, this study examines existing services in Malaysia that suffer not so much due to an inherent fault but due to the lack of awareness about the services. A GBSS program may have no inherent faults such as excessive paperwork or long waiting period, but the lack of awareness about the programs and people's long-held perceptions about the bureaucratic nature of all government initiatives, can lead to its slow uptake. The level of awareness and understanding regarding existing GBSS assistance can also play a role in determining their uptake by prospective entrepreneurs. Therefore, this paper seeks to determine whether knowledge about GBSS affects the decisions of new graduates intending to pursue a career as an entrepreneur. The next section will outline the research framework for this paper, by positing the three constructs of awareness, procedural knowledge and product knowledge of GBSS and generating hypotheses about their impact on the relationship between overall knowledge of GBSS and intention to pursue entrepreneurial activities.

\section{Research Framework}

\subsection{Awareness}

In their study, Khairudin et al. (2009) found that that only $10.1 \%$ of the respondents are aware of the credit guarantee services available in the market in Malaysia while most SMEs are unaware of the existence of the credit guarantee services sponsored by the government in their locality. Their study is supported by previous research such as Abdul Aziz and Faoziah (2009) and Salleh and Ndubisi (2006) who argued that lack of awareness of existence of GBSS was one of the main reasons behind the poor take up rate of entrepreneurship in Malaysia.

Lack of awareness about GBSS among SMEs noted in these studies conducted globally and in Malaysia indicates that entrepreneurs do not have sufficient information about the support programs available. But do students and young graduates intending or considering a career in entrepreneurship also face the same situation? Hypothetically speaking, one may assume that if an SME owner who works full time as an entrepreneur and dedicates his time and energy to the business does not have full knowledge about the support services available, a student new to the field and unfamiliar with its workings will have even lesser knowledge of such services. As proposed by sociological theory, social variables may influence the readiness to venture into business (Luthje \& Franke, 2003). Thus, this study suggests that:

H1: Awareness of the business support services provided by the government among students has a direct effect on the readiness to venture into business

\subsection{Knowledge about the Procedure}

Empirical research shows that services provided by the government usually involves lengthy and complex procedures that require SMEs to have knowledge of the procedure prior to applying for any assistance (Abdul Aziz \& Faoziah, 2009). However, a qualitative study conducted by Hakimin (2010) revealed that some of the SMEs perceived services such as funding as being readily available to any individual who owned an enterprise and filed the necessary forms. Some of the SMEs perceived the procedure to be short and easy and comparable to procedures involved in borrowing funds from private financial institutions. This was due to inaccurate information acquired from unreliable sources such as friends or by word-of-mouth from other social networks. Consequently, this has created a phenomenon of instant entrepreneurs who think of GBSS as a guaranteed and easy support service from government regardless of their lack of personal credentials or past experience in business.

From the researcher's experience, the process of delivering and finalising a contract of service is also delayed or lengthened when users do not follow the procedures. In particular, problems with GBSS also arise because some users perceive the services provided by government as a kind of welfare service that can be easily obtained without preparation and documents to support the application. The moment they are informed about the procedure for availing of such support and the prerequisite of proving their credential as a serious prospective entrepreneur, they are surprised and intimidated by the work involved in the application.

With full knowledge of the procedures and a good understanding of the prerequisites as well as the consequences involved in availing in any GBSS assistance, the propensity of students to venture into business will be improved. Thus, this study suggests that: 
$\mathrm{H} 2$ : Knowledge of procedure of business support services provided by the government has a direct effect on the students' readiness to venture into business.

\subsection{Product Knowledge}

Product knowledge is about familiarity with the product (Alba \& Hutchinson, 1987). Brucks (cited in Lin and Chen (2006) posits that the product knowledge is embedded in the memory or knowledge of consumers. Product knowledge is often used as an independent variable in marketing research because consumers rely on their product knowledge when deciding to purchase a product (Zhu, 2004 in (Lin \& Chen, 2006). Lin and Chen (2006) studied the influence of product knowledge on purchase decision behaviour and Laroche and Nepomuceno (2010) measured the impact of product knowledge on the perceived risk of using it. Both studies found that product knowledge has significant impact on consumer purchase decision and perception. . With regard to this case study, the issue is to determine if there is a relationship between product knowledge of a particular GBSS service and readiness to venture into business. Therefore, the third hypothesis of this study is that:

H3: Knowledge about the product has a direct effect on the students' readiness to venture into business.

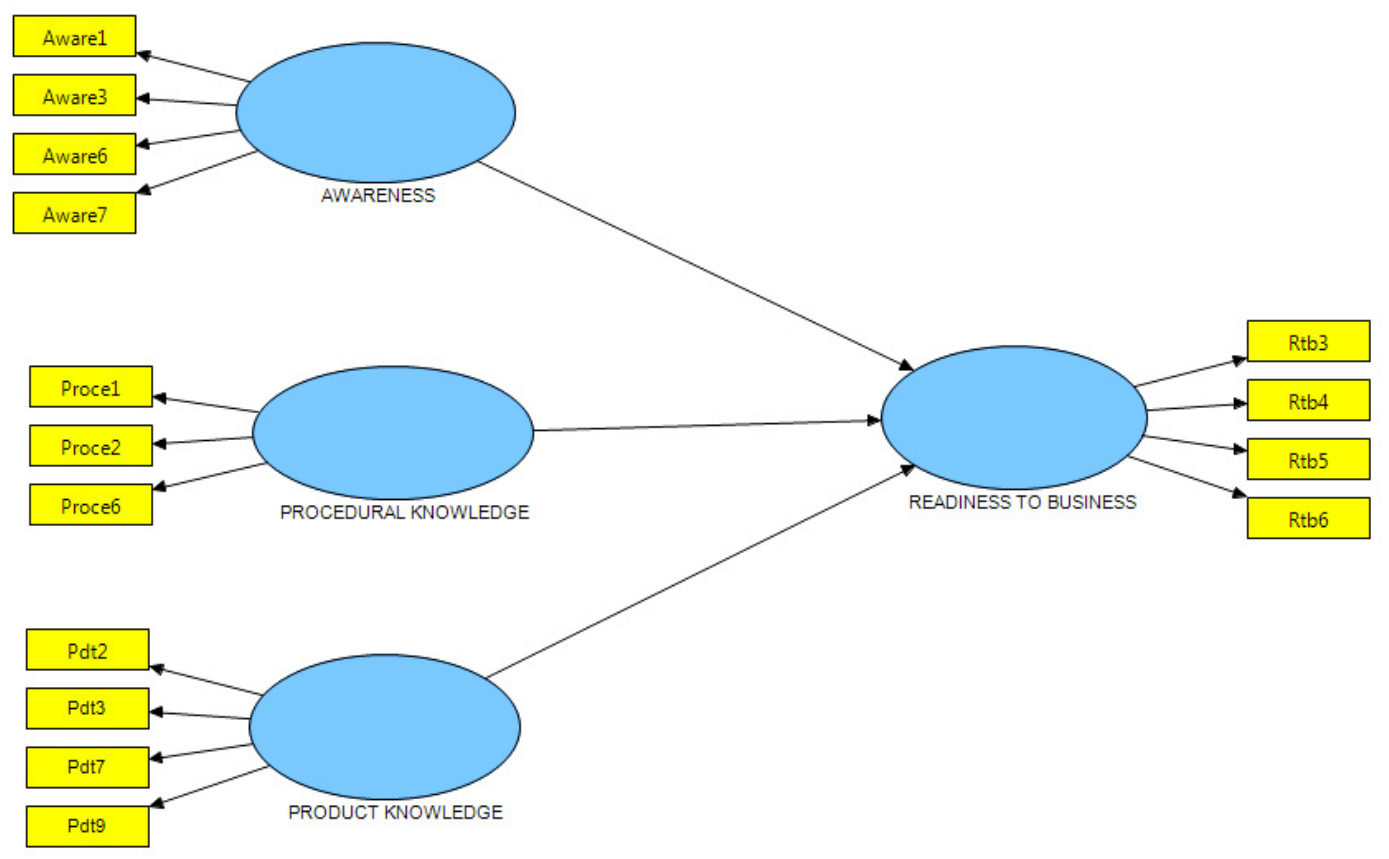

Figure 1. Research framework

\section{Research Findings}

\subsection{Research Sample and Data Collection}

Students from two local universities in Malaysia are used as the sample for empirical analysis of the hypotheses proposed earlier in the paper. This study used non-probability purposive random sampling to choose the respondents for the study. The students who form the sample are pursuing studies in different fields from business, engineering, accountancy, language and sciences at diploma, degree and master level, who have taken up the entrepreneurship course. The demographic information about the respondents is presented in Table 1.

This study used closed-ended survey questionnaires to measure the respondents' intentions about venturing into business. The questionnaires were designed on the basis of the pilot interviews conducted by one of the researchers with two officers from a development financial institution in Kelantan. Further information from literature was also used to include relevant questions and structure the questionnaire (Bennett \& Robson, 1999; Berry, et al., 2006; Dyer \& Ross, 2008). 300 self-administered questionnaires were distributed among two local universities in March 2011. A total of 51 questionnaires were returned (representing a response rate of 17\%) and used for this study. To measure feedback from respondents on the different constructs employed in the research model, the items used a five-point Likert scale. 


\subsection{Assessing Goodness of Measures}

To test the goodness of the measures and their relevance in gauging the attitudes and perceptions of the respondents, a validity and reliability test was conducted. A reliability test tests the consistency of the instruments used to measure concepts whereas a validity test tests the extent to which instruments developed for measuring the concept are capable of capturing it (Hair, Ringle, \& Sarstedt, 2011; Sekaran, 2006).

\subsection{Construct Validity}

Construct validity is used to show that the results from the empirical analysis using the construct fit the theory by examining whether the construct used as the instrument to cover the concept as proposed by the theory succeeds in doing so. This can be done by performing convergent validity and discriminant validity. Before proceeding with the test, PLS algorithm was calculated to obtain loading and cross loading of the item measurement as shown in Table 1. The loading is used to identify any inherent problems with the items used as a construct in the study. According to (Hair, et al., 2011), the cut-off value of loading is around 0.5 and any item with a loading of more than 0.5 can be considered significant. From this calculation, 12 items with loading less than 0.5 was deleted. Table 1 shows that all items measuring particular construct loaded highly on that construct and loaded lower on the other construct thus confirming construct validity (Ramayah, Lee, \& In, 2011).

Table 1. Respondents' demographic information

\begin{tabular}{lcr}
\hline \multicolumn{1}{c}{ Demographic } & Frequency & $\%$ \\
\hline Sex & & \\
Male & 30 & 39.47 \\
Female & 46 & 60.53 \\
Races & & \\
Malay & 58 & 76.32 \\
Chinese & 14 & 18.42 \\
India & 4 & 5.26 \\
Program & & \\
Business & 33 & 43.42 \\
Engineering & 2 & 2.63 \\
Entrepreneurship & 32 & 42.11 \\
Accountancy & 2 & 2.63 \\
Language & 3 & 3.95 \\
Sciences & 4 & 5.26 \\
Level of study & & \\
Certificate & 2 & 2.63 \\
Diploma & 1 & 1.32 \\
Degree & 64 & 84.21 \\
Master & 9 & 11.84 \\
\hline & &
\end{tabular}

\subsection{Convergent Validity}

Secondly, a convergent validity test was performed to ensure that all items measuring constructs are in agreement. Theoretically, all items were related to each other, but it is important to test the convergent validity of the different constructs so that they do not contradict each other and obfuscate the results of the study. In order to do this, the factor loading, composite reliability (CR) and average variance extracted (AVE) was calculated as suggested by Hair et al. (2011). As shown in Table 2, factor loading, CR and AVE exceeded the cut-off values proposed by Hair et al. (2011) at 0.5 for factor loading, 0.7 for CR and 0.5 for AVE. 
Table 2. Loadings and cross loadings

\begin{tabular}{lcccc}
\hline & Awareness & Procedural knowledge & Product knowledge & Readiness to business \\
\hline Aware1 & $\mathbf{0 . 7 9 2}$ & 0.165 & 0.339 & 0.185 \\
Aware3 & $\mathbf{0 . 7 5 0}$ & 0.175 & 0.285 & 0.166 \\
Aware6 & $\mathbf{0 . 6 6 8}$ & 0.364 & 0.392 & 0.092 \\
Aware7 & $\mathbf{0 . 6 6 4}$ & 0.315 & 0.264 & 0.160 \\
Proce1 & 0.272 & $\mathbf{0 . 6 9 6}$ & 0.279 & 0.196 \\
Proce2 & 0.083 & $\mathbf{0 . 7 1 9}$ & 0.155 & 0.201 \\
Proce6 & 0.341 & $\mathbf{0 . 8 2 1}$ & 0.511 & 0.299 \\
Srv2 & 0.210 & 0.249 & $\mathbf{0 . 7 3 4}$ & 0.142 \\
Srv3 & 0.220 & 0.313 & $\mathbf{0 . 7 6 2}$ & 0.187 \\
Srv7 & 0.458 & 0.417 & $\mathbf{0 . 7 4 1}$ & 0.200 \\
Srv9 & 0.322 & 0.291 & $\mathbf{0 . 6 0 8}$ & 0.114 \\
Rtb3 & 0.106 & 0.263 & 0.211 & $\mathbf{0 . 8 1 9}$ \\
Rtb4 & 0.288 & 0.309 & 0.321 & $\mathbf{0 . 8 3 9}$ \\
Rtb5 & 0.123 & 0.206 & 0.084 & $\mathbf{0 . 7 9 3}$ \\
Rtb6 & 0.084 & 0.181 & -0.063 & $\mathbf{0 . 7 0 6}$ \\
\hline
\end{tabular}

Bold values are loadings for items which are above the recommended value at 0.5 .

Table 3. Result of measurement model

\begin{tabular}{lcccc}
\hline Model construct & Measurement item & Loadings & CR & AVE \\
\hline Awareness & Aware1 & 0.792 & 0.811 & 0.519 \\
& Aware3 & 0.750 & & \\
& Aware6 & 0.668 & & \\
Proc know & Aware7 & 0.664 & & \\
& Proce1 & 0.696 & & \\
& Proce2 & 0.719 & 0.791 & 0.558 \\
Pdt know & Proce6 & 0.821 & & \\
& Srv2 & 0.734 & 0.805 & 0.509 \\
& Srv3 & 0.762 & & \\
Srv7 & 0.741 & & \\
Read2 bus & Srv9 & 0.608 & & \\
& Rtb3 & 0.819 & 0.625 \\
& Rtb4 & 0.839 & & \\
& Rtb5 & 0.793 & & \\
& Rtb6 & 0.706 & & \\
\hline
\end{tabular}

Note: Composite reliability $(\mathrm{CR})=$ (square of summation of the factor loadings)/(square of summation of the factor loadings $)+\{$ (square of the summation of the factor loadings) + (square of the summation of the error variances)\}

Average variance extracted $(\mathrm{AVE})=($ summation of the square of the factor loadings $) /\{($ summation of the square of the factor loadings) + (summation of the error variances) $\}$ 
Table 4. Summary of result of the model construct

\begin{tabular}{lccc}
\hline Model construct & Measurement item & Standardized estimates & T-value \\
\hline Awareness & Aware1 & 0.792 & 6.954 \\
& Aware3 & 0.750 & 6.236 \\
Aware6 & 0.668 & 4.654 \\
Proc Know & Aware7 & 0.664 & 4.227 \\
& Proce1 & 0.696 & 6.198 \\
& Proce2 & 0.719 & 8.301 \\
PDT Know & Proce6 & 0.821 & 13.425 \\
& Srv2 & 0.734 & 6.056 \\
& Srv3 & 0.762 & 6.600 \\
Read2 Bus & Srv7 & 0.741 & 5.504 \\
& Srv9 & 0.608 & 4.127 \\
& Rtb3 & 0.819 & 18.279 \\
& Rtb4 & 0.839 & 15.612 \\
& Rtb5 & 0.793 & 11.068 \\
& Rtb6 & 0.706 & 6.910 \\
\hline
\end{tabular}

\subsection{Discriminant Validity}

The degree to which items differentiate among constructs or measure distinct concepts is called discriminant validity. Discriminant validity was assessed by examining correlations between the measures of potentially overlapping constructs (Ramayah, et al., 2011). It is required that items load more strongly on their own constructs in the model than the average variance shared between the constructs (Compeau, Higgins, \& Huff, 1999). As shown in Table 5, the squared correlations for each construct was less than the average variance extracted by the indicators measuring the construct, thus, indicating adequate discriminant validity. In total, the measurement model demonstrated adequate construct validity, convergent validity and discriminant validity.

Table 5. Discriminant validity of constructs

\begin{tabular}{lcccc}
\hline & 1 & 2 & 3 & 4 \\
\hline Awareness & $\mathbf{0 . 5 1 9}$ & & & \\
Procedural knowledge & 0.107 & $\mathbf{0 . 5 5 9}$ & & \\
Product knowledge & 0.184 & 0.206 & $\mathbf{0 . 5 1 0}$ & \\
Readiness to business & 0.048 & 0.102 & 0.054 & $\mathbf{0 . 6 2 6}$ \\
\hline
\end{tabular}

Diagonals (in bold) represent the average variance extracted while the other entries represent the squared correlations

\subsection{Reliability Analysis}

Cronbach's alpha coefficient was used to assess the consistency and stability of the measurement items. Cronbach's alpha coefficient indicates how well the items in a set are positively correlated to one another (Sekaran, 2006). The reliability test of the research model by Cronbach alpha value and the composite reliability value results exhibited values that were at par with the criteria set by other established researchers (Ramayah, et al., 2011). 
Table 6 . Results of reliability test

\begin{tabular}{llccc}
\hline Constructs & Measurement items & Cronbach's $\alpha$ & Loading range & Number of items \\
\hline Awareness & Aware1, Aware2, Aware6, Aware7 & 0.697 & $0.664-0.792$ & $2(8)$ \\
Procedural knowledge & Proce1, Proce2, Proce6 & 0.615 & $0.696-0.821$ & $3(6)$ \\
Product knowledge & Pdt2, Pdt3, Pdt7, Pdt9 & 0.683 & $0.608-0.734$ & $4(9)$ \\
Readiness to business & Rtb3, Rtb4, Rtb5 Rtb6 & 0.813 & $0.706-0.819$ & $4(6)$ \\
\hline
\end{tabular}

Final items numbers (initial numbers)

\subsection{Hypothesis Testing}

A path analysis was conducted to test the hypotheses of the study. The results are presented in Figure 2 and Table 7.

The $\mathrm{R}^{2}$ value was 0.12 indicating that $12 \%$ of the variance of readiness to business can be explained by awareness, procedural knowledge and product knowledge. There were positive relationships between all independent and dependant variables. Awareness was positively related $(\beta=0.104, p<0.01)$ to readiness to business, so was procedural knowledge $(\beta=0.205, p<0.01)$, but product knowledge was not a significant predictor of readiness to business. Further analysis found that, procedural knowledge was the most significant predictor of readiness to business followed by awareness. The higher the knowledge of procedure to acquire the services, the higher was the propensity to venture into business. This resonates with a study by Luthje and Franke (2003) which found that the knowledge of procedures in obtaining perceived support has a positive relationship with the intention to choose entrepreneurship as a career.

Table 7. Path coefficient and hyphothesis testing

\begin{tabular}{llccc}
\hline Hypothesis & Relationship & Coefficient & t- value & Supported \\
\hline $\mathrm{H} 1$ & AWARE $\longrightarrow$ RTB & 0.104 & 1.466 & YES \\
H2 & PROCE $\longrightarrow$ RTB & 0.252 & 3.569 & YES \\
H3 & PDT $\longrightarrow$ RTB & 0.074 & 0.800 & NO \\
\hline
\end{tabular}

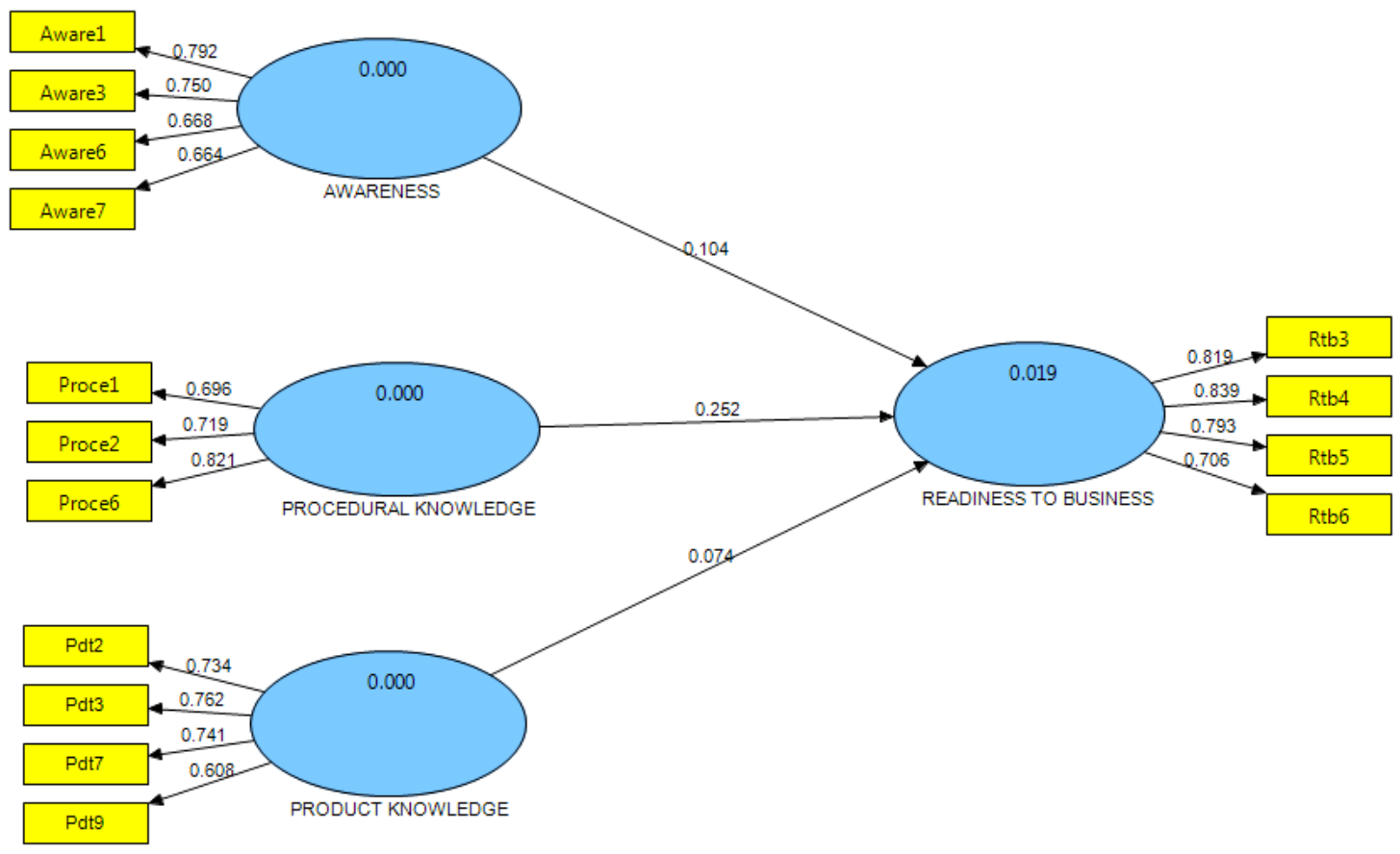

Figure 2. Results of the path analysis 


\section{Discussion and Conclusion}

The findings of this study confirmed the views established by other studies that awareness about GBSS has an impact on the behaviours and perceptions of the respondents as proposed by the sociological theory (Berry, et al., 2006; Luthje \& Franke, 2003). The findings support other studies conducted on the influence of awareness on the degree of usage of government services (Khairudin, 2007). In particular, it found that awareness of GBSS and procedural knowledge affected the students' intentions, but product knowledge did not have any significant impact on students' readiness to venture into business. It was found that knowledge of procedure has the greatest influence on the students' readiness to venture into business of all the three factors. The insignificant relationship between product knowledge and readiness to venture may be due to the effect of several factors, such as inferior perceived brand image (Bian \& Moutinho, 2011).

Although the impact of awareness about GBSS on readiness of prospective entrepreneurs has been generally acknowledged, this hypothesis has not been tested on university students. This issue is of critical importance in the Malaysian context because the local government via ministry of higher learning is not only actively promoting entrepreneurship as a career it is also allocating extensive resources for financial and logistical support to graduate entrepreneurs. The findings of this study not only validate the rationale behind such expenditure but also add to the body of knowledge for the curriculum taught in entrepreneurship courses in universities. Currently, knowledge about the external support provided by GBSS is embedded in the university curriculum but it is very limited and is only taught in one chapter in the entrepreneurship program. Also, the discussion is not detailed enough to convey a good knowledge of GBSS and the procedures involved in acquiring their services are not discussed at all. Given the impact of knowledge about GBSS on student intention to adopt a career in entrepreneurship proved by this study, it is suggested that the discussion about the GBSS available should be embedded in the curriculum as a compulsory subject and taught to all students across different disciplines. Early preparation and preliminary research about the procedures stipulated by service providers will enable future entrepreneurs to do the right thing to get the services. On the other hand, government agencies can publicise their programs and make the procedures clear and understandable for the intended users. This will also help reduce the negative perception of prospective users about the lengthy process and bureaucracy involved in GBSS programs and remove future complications at the time of application.

\section{Limitations \& Future Research}

Due to the localised nature of the study as well as small sample size involved, the findings of this study cannot be presented as a generalisation. This becomes a major limitation when the small sample of two universities is considered against the fact that there are 20 large public universities in the country. It is suggested that future studies could perhaps use samples from all of the public universities in the country to present an overall picture for young graduate entrepreneurs in Malaysia. Future studies could also examine the role of entrepreneurial orientation (EO) to moderate the relationship between independent and dependent variables. EO has recently received great attention from researchers as a critical construct for establishing the determinants of appropriate behaviour that make a successful entrepreneur. It would be interesting to explore the moderating effect of EO on the propensity of young graduates to pursue a career in entrepreneurship.

\section{References}

Abdul Aziz, L., \& Faoziah, I. (2009). Entrepreneurs' awareness of bank borrowing offered by government agencies and commercial bank. Kelantan: Universiti Malaysia Kelantan.

Barney, J., Wright, M., \& Ketchen, D. J. J. (2001). The resource-based view of the firm: Ten years after 1991. Journal of Management, 27, 625-641. http://dx.doi.org/10.1177/014920630102700601

Bennett, R. J., \& Robson, P. J. A. (1999). The use of external business advice by SMEs in Britain. Entrepreneurship \& Regional Development, 11(2), 155-180. http://dx.doi.org/10.1080/089856299283245

Berry, J. A., Sweeting, R., \& Goto, J. (2006). The effect of business advice on the performance of SMEs. Journal of Small Business and Enterprise Development, 13(1), 33-47. http://dx.doi.org/10.1108/14626000610645298

Bian, X., \& Moutinho, L. (2011). The role of brand image, product involvement, and knowledge in explaining consumer purchase behaviour of counterfeits: direct and indirect effects. European Journal of Marketing, 45(1/2), 191-216. http://dx.doi.org/10.1108/03090561111095658

Boter, H., \& Lundstrom, A. (2006). SME Perpectives on Business Support Services. Journal of Small Business 
and Enterprise Development, 12(2), 244-258. http://dx.doi.org/10.1108/14626000510594638

Caniels, C. J. M., \& Romjin, A. H. (2006). What works and why, in business services provision for SMEs: Insights from evolutionary theory. Managing Service Quality, 15(6), 591-608. http://dx.doi.org/10.1108/09604520510634041

Chrisman, J. J., Mc Mullan, E., \& Hall, J. (2005). The influence of guided preparation on the long-term performance of new ventures. Journal of Business Venturing, 20, 769-791. http://dx.doi.org/10.1016/j.jbusvent.2004.10.001

Compeau, D., Higgins, C. A., \& Huff, S. (1999). Social cognitive theory and individual reactions to computing technology: a longitudinal-study. MIS Quarterly, 23(2), 145-158. http://dx.doi.org/10.2307/249749

Dahlan, I., Hakimin, Y., \& Azwin, N. (Eds.). (2010). The relationship between tacit knowledge and entrepreneurial orientation among university students (Vol. 1). Kelantan: Universiti Malaysia Kelantan.

Delmar, F., \& Davidsson, P. (2000). Where do they come from? Prevalence and characteristics of nascent entrepreneurs. Entrepreneurship \& Regional Development, $12(1), \quad 1-23$. http://dx.doi.org/10.1080/089856200283063

Dyer, L. M., \& Ross, A. C. (2008). Seeking advice in a dynamic and complex business environment: Impact on the success of small firms. Joournal of Development Entrepreneurship, 13(2), 133-149. http://dx.doi.org/10.1142/S1084946708000892

Gorman, G., Hanlon, D., \& King, W. (1997). Some research perspective on entrepreneurship education, enterprise education and education for small business management: A ten year literature review. International Small Business Journal, 15(3), 56-77. http://dx.doi.org/10.1177/0266242697153004

Hair, F. J., Ringle, M. C., \& Sarstedt, M. (2011). PLS-SEM: Indeed a silver bullet. Journal of Marketing Theory and Practice, 19(2), 139-151. http://dx.doi.org/10.2753/MTP1069-6679190202

Hakimin, Y. (2010). The utilisation of the government business support services: The senior adviser perspectives (Vol. 1). Kelantan: Universiti Malaysia Kelantan.

Jay, L., \& Schaper, M. (2003). Which advisers do micro-firms use? Some Australian evidence. Jounal of Small Business and Enterprise Development, 10(2), 136-143. http://dx.doi.org/10.1108/14626000310473166

Khairudin, H. (2007). Entrepreneurship in Malaysia. Sintok: Universiti Utara Malaysia.

Laroche, M., \& Nepomuceno, V. (2010). How do involvement and product knowledge affect the relationship between intangibility and perceived risk for brands and product categories? Journal of Consumer Marketing, 27(3), 197-210. http://dx.doi.org/10.1108/07363761011038275

Lin, L. Y., \& Chen, C. S. (2006). The influence of the country-of-origin image, product knowledge and product involvement on consumer purchase decisions: an empirical study of insurance and catering services in Taiwan. Journal of Consumer Marketing, 23(5), 248-265. http://dx.doi.org/10.1108/07363760610681655

Luthje, C., \& Franke, N. (2003). The 'making' of an entreprenur: testing a model of entrepreneurial intent among $\begin{array}{lllll}\text { engineering students at } & \text { MIT. } R \& D \quad \text { Management, } 33(2), & 135-147 .\end{array}$ http://dx.doi.org/10.1111/1467-9310.00288

Moha Asri, A., Abdul Aziz, L., Mohd Isa, B., \& Norizan, M. N. (2001). The Outreach of Support Programmes for Bumiputra's Entrepreneurs in SMEs: Evidence from Malaysia.

Mole, F. K., Hart, M., Roper, S., \& Saal, S. D. (2009). Assessing the effectiveness of business support services in England : Evidence from a Theory-Based Evaluation. International Small Business Journal, 27(5), 557-582. http://dx.doi.org/10.1177/0266242609338755

National SME Development Council. (2009). SME Annual Report (pp. 21).

Penrose, E. (2009). The Theory of The Growth of The Firm (4 ed.). Oxford University Press.

Ramayah, T., Lee, J. W. C., \& In, J. B. C. (2011). Network collaboration and performance in the tourism sector. Service Business, 5, 411-428. http://dx.doi.org/10.1007/s11628-011-0120-z

Ramsden, M., \& Bennet, R. J. (2005). The Benefit of External Support to SMEs. "Hard" versus "Soft" outcomes and Satisfaction Levels. Jounal of Small Business and Enterprise Development, 12(2), 227-243. http://dx.doi.org/10.1108/14626000510594629

Salleh, A. S., \& Ndubisi, N. O. (2006). An Evaluation of SME Development in Malaysia. International Review 
of Business Research Papers, 2(1), 1-14.

Sekaran, U. (2006). Research Methods For Business. A Skill Building Approach (4th ed.). New Delhi: John Wiley \& Sons, Inc.

Souitaris, V., Zerbinati, S., \& Al-Laham, A. (2007). Do entrepreneurship programmes raise entrepreneurial intention of science and engineering students? The effect of learning, inspiration and resources. Journal of Business Venturing, 22(4), 566-591. http://dx.doi.org/10.1016/j.jbusvent.2006.05.002

Tan, S. S., \& Ng, F. C. K. (2006). A problem-based learning approach to entrepreneurship education. Education + Training, 48(6), 416-428.

Wiklund, J., \& Shepherd, D. (2003). Knowledge-based resources, entrepreneurial orientation-performance relationship, and the performance of small and medium sized businesses. Strategic Management Journal, 24, 1307-1314. http://dx.doi.org/10.1002/smj.360

Wren, C., \& Storey, J. D. (2002). Evaluating the effect of soft business support upon small firm performance. Oxford Economic Papers, 54(2), 334. http://dx.doi.org/10.1093/oep/54.2.334 